\title{
PKW Budidaya Sayuran Hidroponik di Desa Pekalongan Kecamatan Batealit Kabupaten Jepara
}

\author{
Akhmad Syakhroni ${ }^{1}$, M. Sagaf ${ }^{*}$, Novi Marlyana ${ }^{3}$ \\ 1,2,3Teknik Industri, Fakultas Teknologi Industri, Universitas Islam Sultan Agung, Jl. \\ Raya Kaligawe Km. 4, Semarang 50112. Telp : (024) 6583584, \\ syakhroni@unissula.ac.id, msagaf@unissula.ac.id, novi@unissula.ac.id
}

*Korespondensi : msagaf@unissula.ac.id

Diterima: 12 November 2021 ; Review: 18 November 2021 ; Disetujui: 26 Desember 2021 ; Diterbitkan: 31 Desember 2021

\begin{abstract}
One of the hydroponic vegetable cultivators in Jepara district, Mr. Ryan Arfian with his business named Bagus Hydrofarm (Mitra) has problems in the field of low production capacity. This is because partners only have 800 mature planting points. The production process of hydroponic vegetables is also still low because there is no quality control on the product. This problem arises because there is no partner's knowledge about the production process and quality control that is sufficient and good. there is no humidity and temperature measuring instrument. The results of the increased benefits from this regional partnership program are an increase in production capacity by $17.5 \%$, an increase in knowledge of how to cultivate hydroponic vegetables by $100 \%$, an increase in assets in the form of measuring instruments for PH and TDS by $100 \%$, an increase in assets in the form of measuring devices for temperature and humidity by $100 \%$, increased knowledge about good business management by $100 \%$.
\end{abstract}

Keywords : Hydroponics, PH and TDS, temperature and humidity

\begin{abstract}
Abstrak
Salah satu pembudidaya sayuran hidroponik di kabupaten Jepara Bapak Ryan Arfian dengan usahanya yang bernama Bagus Hydrofarm (Mitra) memiliki permasalahan di bidang kapasitas produksi yang rendah. Hal ini dikarenakan mitra hanya mempunyai 800 titik tanam dewasa. Proses produksi sayuran hidroponik juga masih rendah karena belum adanya kontrol kualitas pada hasil produksinya. Permasalahan tersebut muncul karena belum adanya pengetahuan mitra mengenai proses produksi dan kontrol kualitas yang cukup dan baik. Selain itu juga disebabkan oleh belum adanya alat untuk mengetahui kandungan nutrisi pada air dan belum adanya alat ukur kelembaban dan suhu. Managemen usaha pada mitra juga masih dikelola secara sederhana dan kekeluargaan.untuk mengatasi permasalahan tersebut, metode yang digunakan antara lain sosialisasi, pendampingan, monitoring dan evaluasi. Hasil peningkatan manfaat dari program kemitraan wilayah ini adalah peningkatan kapasitas produksi sebesar $17,5 \%$, peningkatan pengetahuan cara budidaya sayuran hidroponik sebesar $100 \%$, peningkatan aset berupa alat ukur PH dan TDS sebesar $100 \%$, peningkatan aset berupa alat pengukur suhu dan kelembaban sebesar $100 \%$, peningkatan pengetahuan tentang manajemen usaha yang baik sebesar $100 \%$.
\end{abstract}

Kata kunci : Hidroponik, PH dan TDS, suhu dan kelembapan 


\section{PENDAHULUAN}

Kabupaten Jepara meskipun berada di pesisir pantai tetapi juga memiliki daerah pegunungan yang beriklim sejuk dikarenakan ketinggian permukaan tanah dari permukaan air laut wilayah Kabupaten Jepara terletak mulai dari $0 \mathrm{~m}$ sampai dengan $1.301 \mathrm{~m}$ (Sagaf et al., 2021). Luas wilayah Kabupaten Jepara tercatat 100.413,189 ha. Dengan curah hujan pada tahun 2020 terendah sebesar $32 \mathrm{~mm}$ pada bulan Juli dan tertinggi sebesar $1301 \mathrm{~mm}$ pada bulan Februari (Badan Pusat Statistik Kabupaten Jepara, 2021). Kecamatan Batealit terkenal sebagai penghasil komoditas ukir dan mebel berkualitas akan tetapi untuk pemenuhan kebutuhan sayuran masih sangat kurang karena banyak dipasok dari daerah bandungan atau pegunungan yang mempunyai jarak cukup jauh dari Batealit Jepara, sehingga pada musim kemarau jumlah pasokan sayurnya sangat terbatas, dan hal ini menyebabkan harga sayuran di pasar melonjak tinggi mencapai 2 kali lipat pada harga umumnya. Oleh karena itu sebagian kelompok tani modern berbasis sistem hidroponik mencoba menerapkan budidaya sayur di cuaca yang panas seperti di Jepara yang mencapai suhu rata-rata $32^{\circ} \mathrm{C}$. Pertanian ini dapat dilakukan secara kecil-kecilan sebagai hobi ataupun secara besar untuk tujuan komersil (Izzuddin, 2016).

Salah satu petani hidroponik Bagus Hydrofarm yang dimiliki Bapak Ryan Arfian merupakan salah satu diantara beberapa petani hidroponik yang ada di kecamatan Batealit kabupaten Jepara. Lokasi budidaya ini berada di desa Pekalongan kecamatan Batealit Kabupaten Jepara.

Petani ini mempunyai fasilitas lahan seluas $75 \mathrm{~m} 2$ dengan dilengkapi 1 buah meja untuk masa tanam remaja dengan kapasitas 400 titik tanam dan 4 buah meja sistem NFT (Nutrien Film Technique) (Swastika et al., 2017) untuk masa tanam dewasa dengan jumlah total 800 titik tanam. Masa panen sayuran selama 45 HSS (hari setelah semai) dengan berat tanaman rata-rata mencapai 150 gram/tanaman.

Permasalahan yang terjadi pada mitra adalah hasil panen sayuran petani ini belum maksimal dan banyak tanaman yang mati. Selain itu pengaturan suhu dan kelembaban greenhouse pada saat cuaca panas juga dilakukan secara manual dengan menyemprotkan air PDAM menggunakan selang jika melihat kondisi tanaman mulai layu. Sehingga diperlukan tenaga manusia untuk melakukan hal ini dan harus sering dilakukan pengecekan suhu oleh petani. Pengecekanpun dilakukan secara manual menggunakan perasaaan tanpa menggunakan alat pengukur suhu dan kelembaban. Pemberian nutrisi pada tanaman juga masih dilakukan secara manual. Dengan cara ditakar menggunakan gelas ukur dan hanya menggunakan perbandingan, tanpa menggunakan alat ukur kadar larutan air. Sehingga kandungan nutrisi pada air tidak dapat dikontrol dengan baik, sangat tergantung dari kerajinan petani untuk mengecek kondisi air. Kapasitas produksi (hasil panen) juga belum mencukupi untuk memenuhi kebutuhan pasar sayuran hidroponik di sekitar Jepara. Sehingga saat ada permintaan yang melonjak tidak dapat memenuhi. Sistem manajemen usaha yang digunakan juga hanya berdasarkan pengalaman dan pengetahuan seadanya serta belum adanya sistem pembukuan yang baik.

\section{ANALISIS SITUASI}

Analisis permasalahan dari latar belakang yang ada adalah kondisi mitra dimana pengecekan suhu dan kelembapan serta pemberian nutrisi masih dilakukan secara manual. Selain itu kapasitas produksi (hasil panen) juga belum mencukupi untuk memenuhi kebutuhan pasar sayuran hidroponik di sekitar Jepara. Sistem manajemen usaha yang digunakan juga hanya berdasarkan pengalaman dan pengetahuan seadanya serta belum adanya sistem pembukuan yang baik. Berdasar permasalahan tersebut tim berusaha untuk dapat membantu memaksimalkan usaha budidaya sayuran hidroponik dengan berbagai solusi yang ditawarkan. 


\section{METODE PELAKSANAAN}

Metode pelaksanaan kegiatan Program Kemitraan Wilayah dalam rangka meningkatkan kapasitas produksi sayuran hidroponik adalah sebagai berikut :

a) Metode transfer teknologi dan penerapan iptek

Transfer teknologi pada mitra budidaya sayuran hidropponik adalah sistem atau teknik budidaya dengan mengontrol kualitas kandungan nutrisi pada air, dan peningkatan kapasitas tanam dewasa yang diharapkan mampu memenuhi kebutuhan pasar sayuran hidroponik, yang saat ini belum mampu dipenuhi.

b) Sosialisasi dan pelatihan manajemen usaha

Pelaksanaan kegiatan ini dilakukan dengan memberikan sosialisasi dan pelatihan pada mitra tentang bagaimana cara managemen usaha yang baik.

c) Monitoring dan Evaluasi

Kegiatan ini ditujukan untuk melihat perkembangan program pengabdian yang telah dilaksanakan.

\section{HASIL DAN PEMBAHASAN}

Pelaksanaan kegiatan program kemitraan wilayah ini dilakukan dalam beberapa kegiatan antara lain :

\subsection{Persiapan Kegiatan}

Untuk mempersiapkan program kegiatan yang akan dilakukan tim memulainya dengan melakukan survey pendahuluan ke tempat mitra untuk melihat kondisi terakhir mitra.Pelaksanaan kegiatan ini dilakukan tanggal 17 September 2021

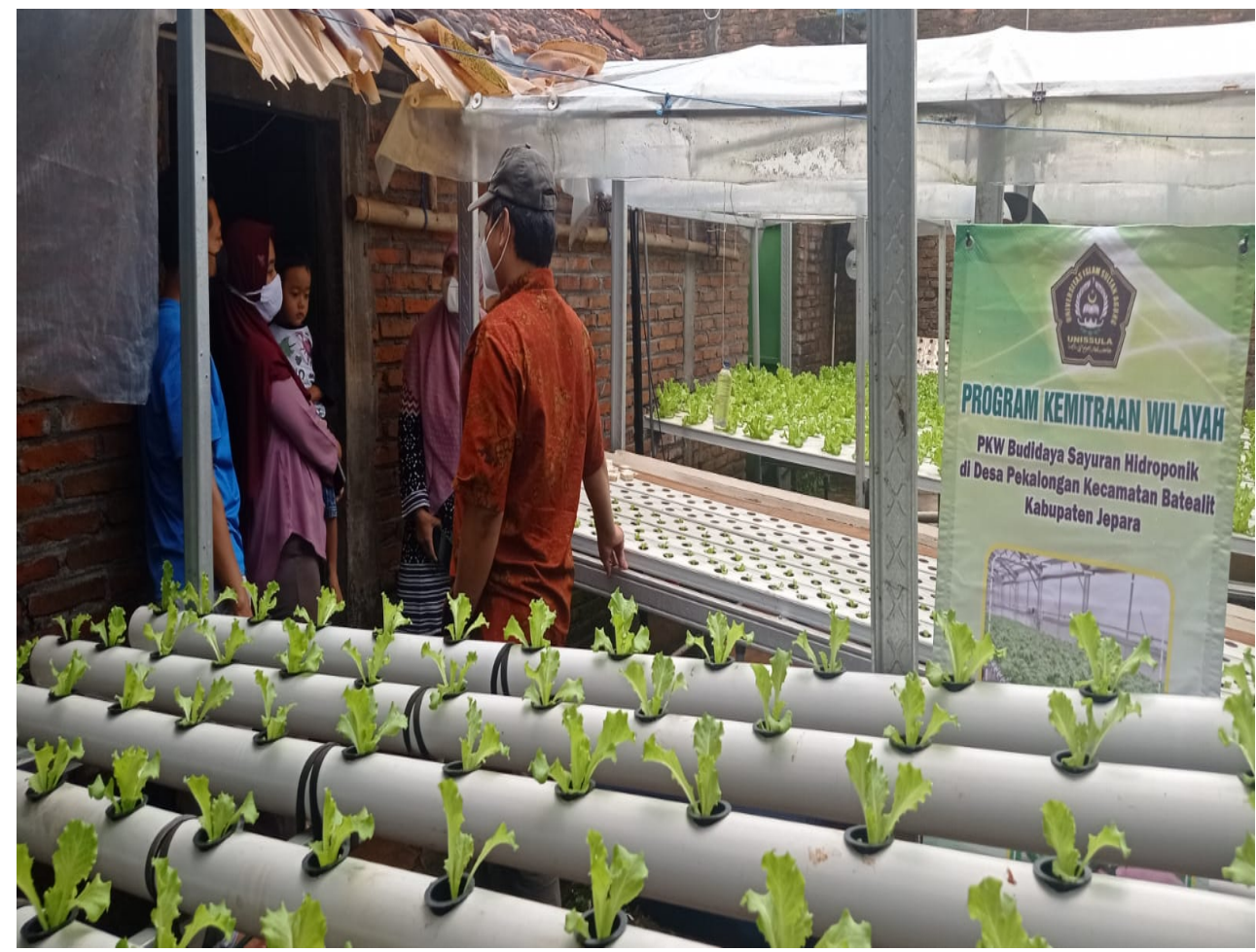

Sumber : Hasil Pelaksanaan (2021)

Gambar 1. Survey ke Tempat Mitra

\subsection{Sosialisasi Program Pengabdian Pada Mitra}

Setelah survey dilakukan kegiatan selanjutnya adalah sosialisasi program pengabdian kepada mitra. Disini tim dosen datang ke tempat mitra untuk memberikan pengetahuan pada mitra mengenai kegiatan yang akan dilakukan dalam program pengabdian ini.Kegiatan sosialisasi ini dilakukan bersamaan dengan survey tempat mitra yaitu tanggal 17 September 2021. 


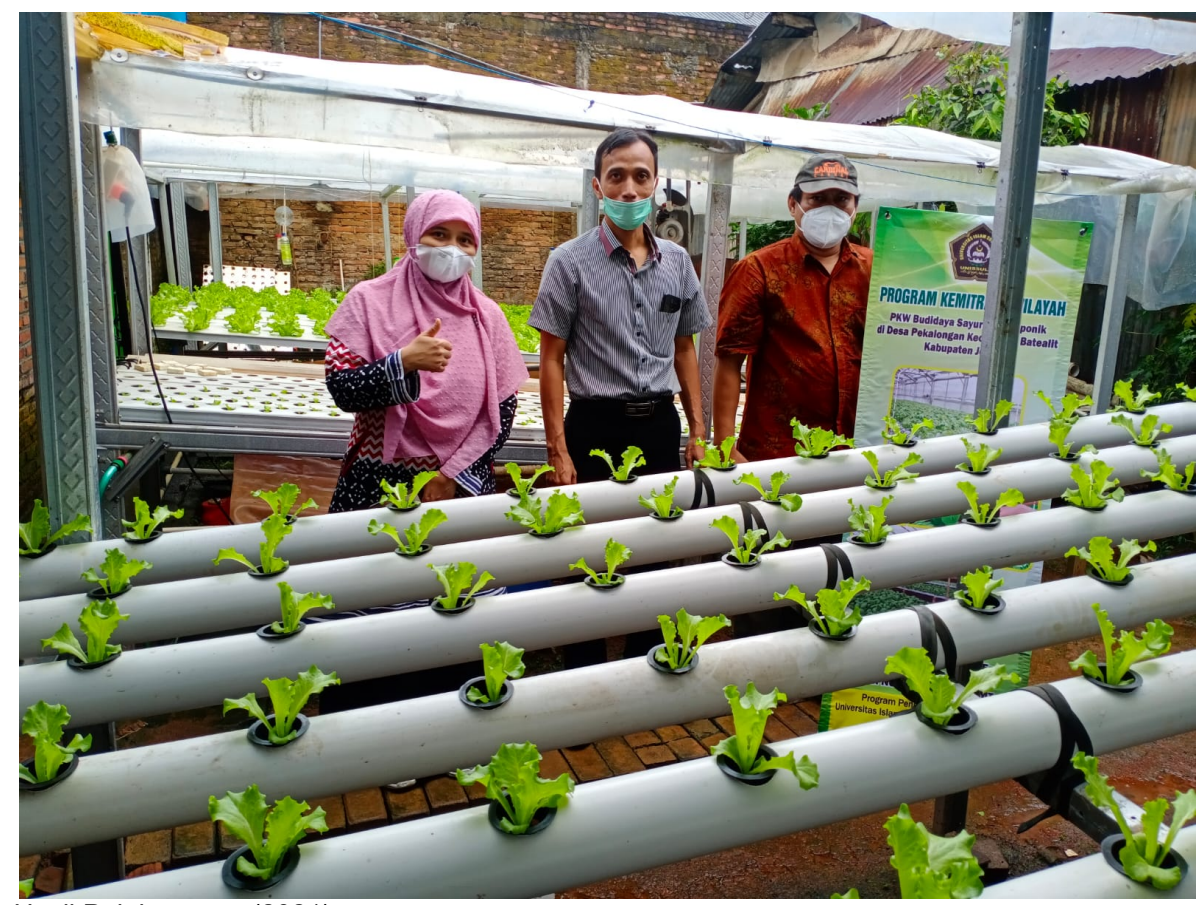

Sumber : Hasil Pelaksanaan (2021)

Gambar 2. Sosialisasi Program Pengabdian

\subsection{Pelatihan dan Pendampingan Penggunaan Alat Ukur PH dan TDS serta Alat} Pengukur Suhu dan Kelembapan (Aksa et al., 2018)

Kegiatan ini penting dilakukan karena mitra selama ini belum pernah menggunakan alat-alat tersebut dan hanya melakukan secara manual saja. Dengan adanya kegiatan ini diharapkan mitra dapat menggunakan teknologi tepat guna untuk dapat mengembangkan usaha budidaya sayuran hidroponik tersebut. Kegiatan ini dilaksanakan dengan narasumber Bapak M. Sagaf, ST. MT dan Bapak Achmad Syahroni, ST. M Eng selaku akademisi dan praktisi yang berpengalaman di bidangnya. Kegiatan ini dilakukan pada tanggal 22 Oktober 2021.

Sumber : Hasil Pelaksanaan (2021)

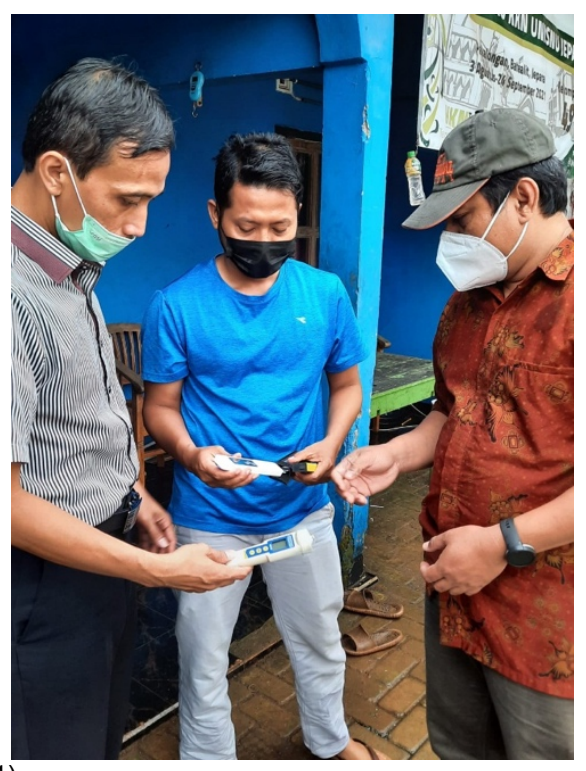

Gambar 3. Pelatihan dan Pendampingan Penggunaan Alat Teknologi Tepat Guna oleh 


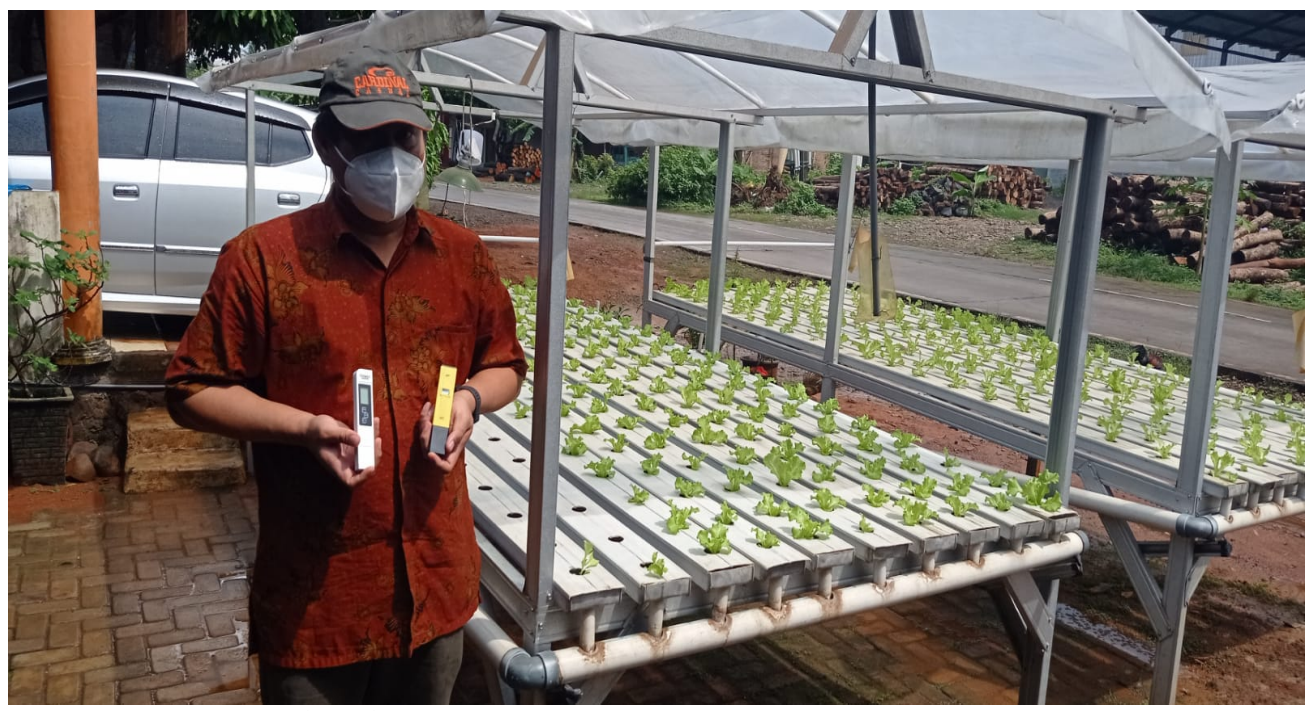

Sumber : Hasil Pelaksanaan (2021)

Gambar 4. Pelatihan Penggunaan Alat Teknologi Tepat Guna oleh Bapak Akhmad Syakhroni, S.T., M.Eng

\subsection{Pelatihan Managemen usaha}

Selain kegiatan pendampingan penggunaan alat ukur $\mathrm{PH}$ dan TDS serta alat pengukur suhu dan kelembapan, tim dosen juga melakukan pelatihan manajemen usaha dimana mitra sebelumnya hanya menggunakan sistem manajemen usaha yang berdasarkan pengalaman dan pengetahuan seadanya serta belum adanya sistem pembukuan yang baik. Dengan adanya kegiatan ini diharapkan agar mitra dapat mengembangkan kemampuan managemen usaha menjadi lebih baik. Pelaksanaan kegiatan ini bersamaan dengan pelatihan penggunaan alat ukur $\mathrm{PH}$ dan TDS yaitu tanggal 22 Oktober 2021. Kegiatan ini dilaksanakan dengan narasumber lbu Novi Marlyana, ST. MT selaku akademisi dan praktisi yang berpengalaman di bidangnya

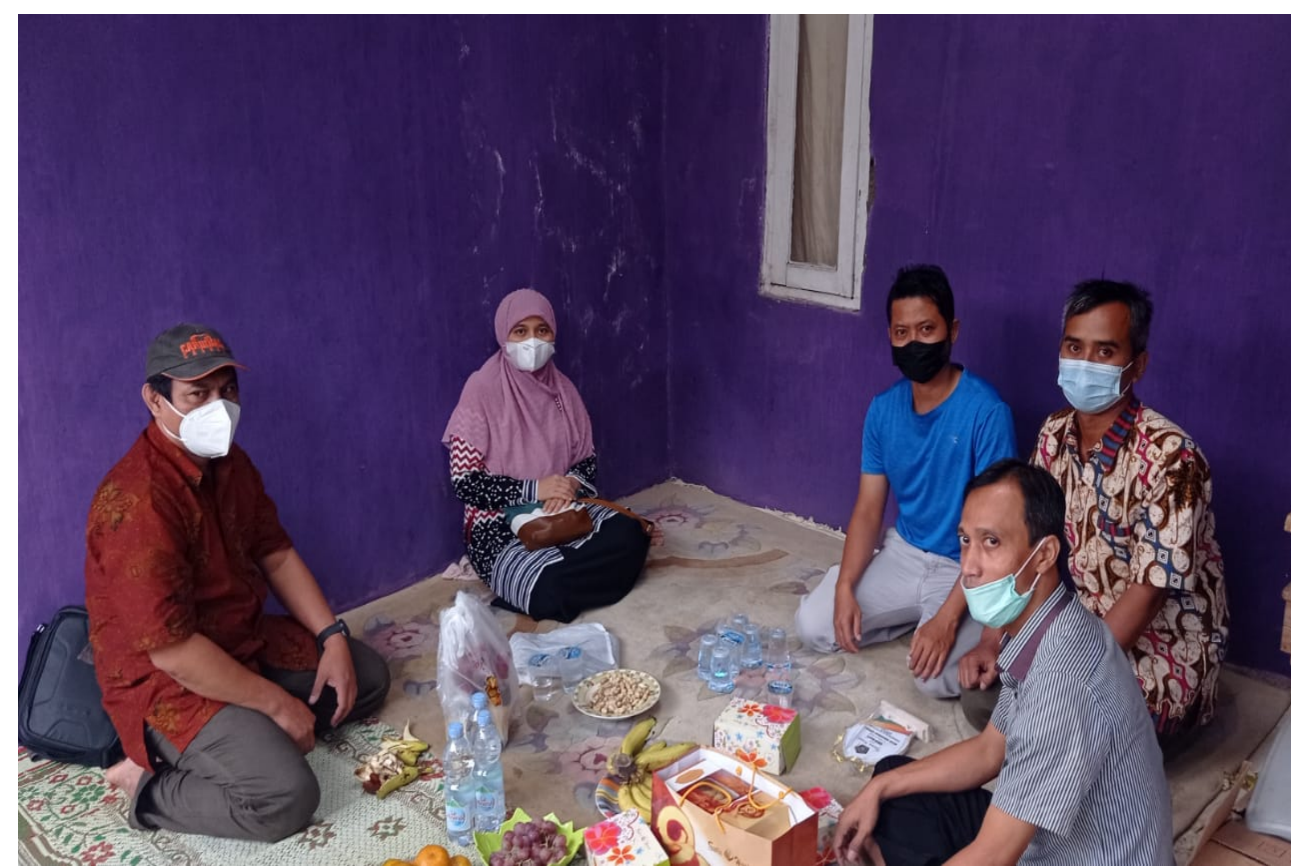

Sumber : Hasil Pelaksanaan (2021)

Gambar 5. Pelatihan Manajemen Usaha 


\subsection{Penambahan Jumlah Titik Tanam}

Pada Program Kemitraan Wilayah ini juga diadakan peningkatan kapasitas usaha dengan cara penambahan jumlah titik masa tanam dewasa sebanyak 140 buah dimana sebelum diadakan kegiatan PKW ini jumlah titik masa tanam dewasa sebanyak 800 buah dan setelah adanya program ini meningkat menjadi 940 buah.

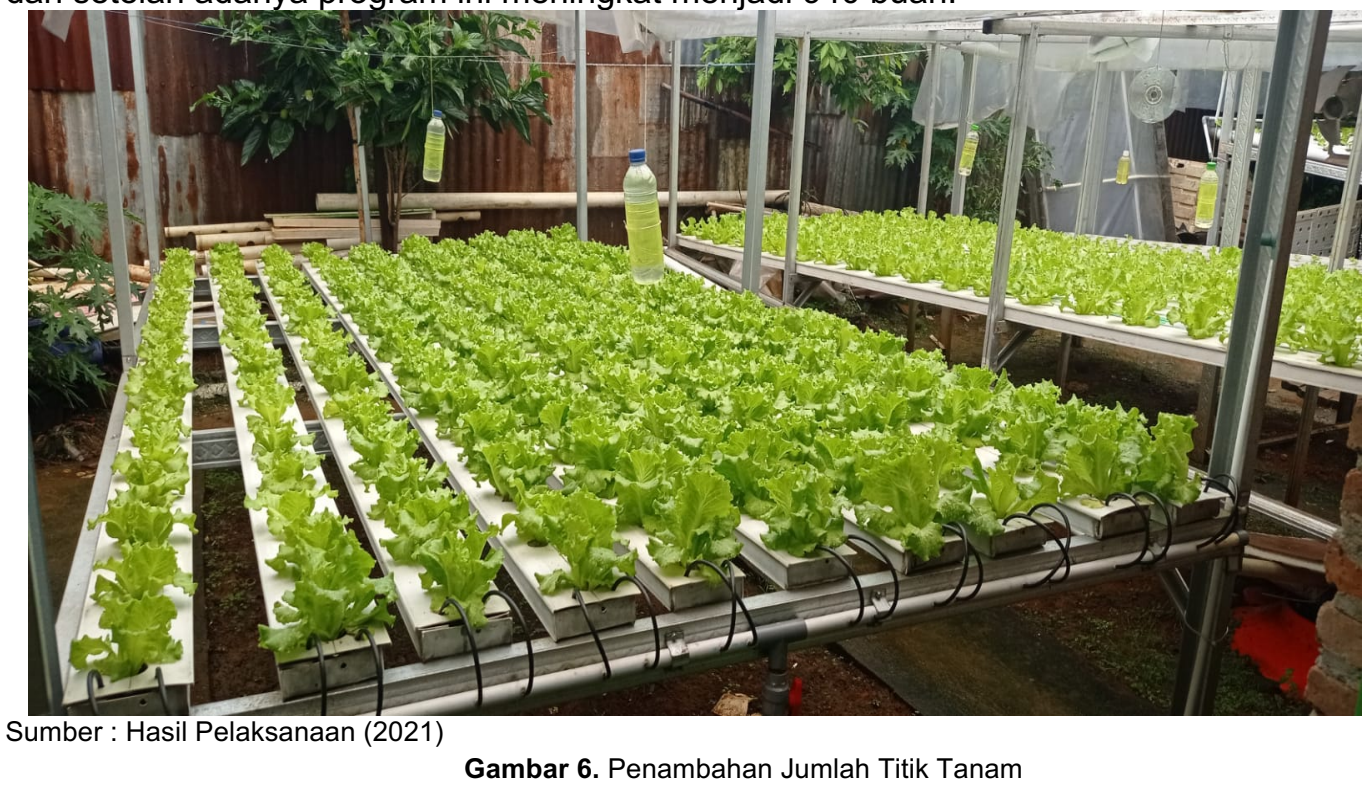

\subsection{Monitoring dan Evaluasi}

Pelaksanaan kegiatan ini dilakukan pada tanggal 7 November 2021. Kegiatan ini ditujukan untuk melihat perkembangan program yang telah dilaksanakan dan mengevaluasinya.

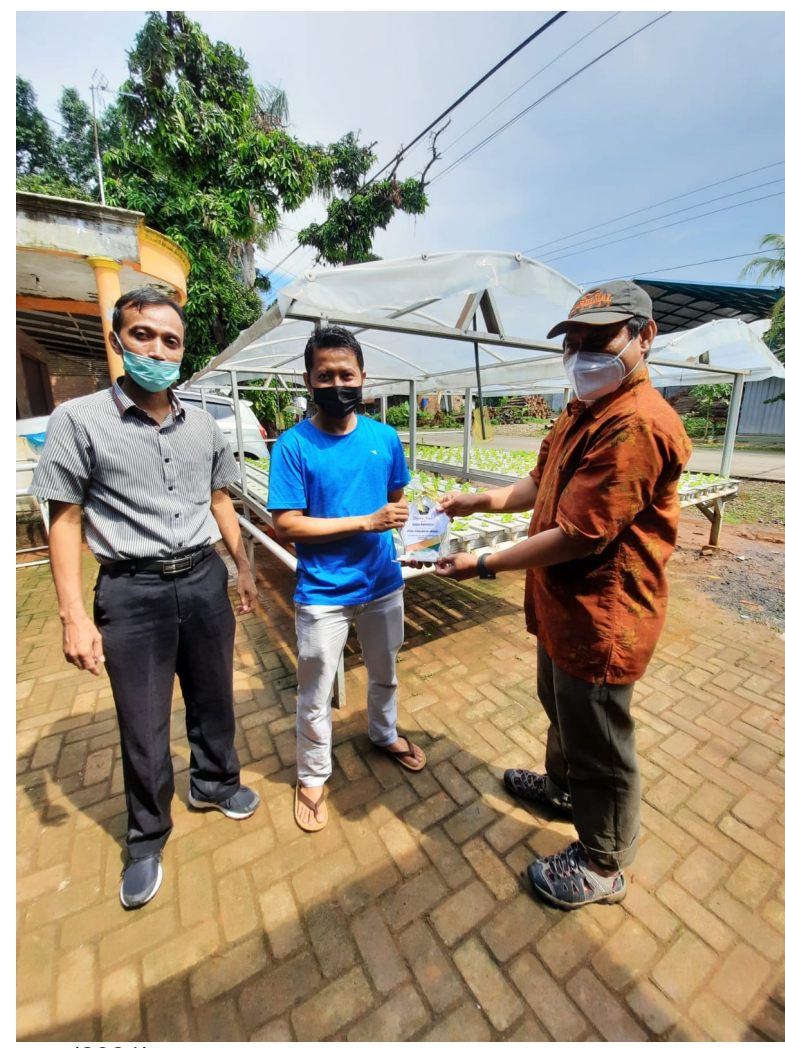

Sumber : Hasil Pelaksanaan (2021)

Gambar 7. Monitoring dan Evaluasi 
Peningkatan manfaat yang diperoleh secara keseluruhan dari diadakannya program pengabdian ini dapat dilihat dengan jelas pada tabel di bawah ini :

Tabel 1. Peningkatan Manfaat yang Diperoleh

\begin{tabular}{llll}
\hline Aspek Ekonomi dan Sosial & $\begin{array}{l}\text { Sebelum } \\
\text { Pelaksanaan } \\
\text { PKW }\end{array}$ & $\begin{array}{l}\text { Setelah } \\
\text { Pelaksanaan } \\
\text { PKW }\end{array}$ & $\begin{array}{l}\text { Peningkatan } \\
\text { (\%) }\end{array}$ \\
$\begin{array}{l}\text { Menambah jumlah titik masa } \\
\text { tanam dewasa sebanyak } 140 \\
\text { buah }\end{array}$ & 800 buah & 940 buah & $17,5 \%$ \\
\hline $\begin{array}{l}\text { Pengetahuan cara budidaya } \\
\text { sayuran hidroponik yang baik }\end{array}$ & Belum tahu & Tahu & $100 \%$ \\
\hline $\begin{array}{l}\text { Kemampuan manajemen usaha } \\
\text { yang baik }\end{array}$ & Belum mampu & Mampu & $100 \%$ \\
\hline $\begin{array}{l}\text { Alat ukur PH dan kandungan TDS } \\
\text { pada larutan. }\end{array}$ & Belum ada & Ada & $100 \%$ \\
\hline $\begin{array}{l}\text { Alat pengukur suhu dan } \\
\text { kelembapan }\end{array}$ & Belum ada & Ada & $100 \%$ \\
\hline
\end{tabular}

\section{KESIMPULAN DAN REKOMENDASI}

Melalui kegiatan program Kemitraan Wilayah ini telah dihasilkan dan digunakan alat ukur PH dan kandungan TDS pada larutan serta alat pengukur suhu dan kelembaban. Mitra dalam kegiatan ini juga telah dapat mengaplikasikan teknologi alat ukur $\mathrm{PH}$ dan kandungan TDS pada larutan serta alat pengukur suhu dan kelembapan dengan baik yang berguna untuk meningkatkan kuantitas dan kualitas dari produksi sayuran hidroponik. Kapasitas usaha sayuran hidroponik juga dapat ditingkatkan dengan adanya penambahan jumlah titik masa tanam dewasa sebanyak 140 buah. Selain itu kemampuan managemen usaha mitra juga berjalan baik dengan adanya kegiatan ini. Dari hasil yang dicapai dapat disarankan yaitu perlu kiranya di lakukan penyuluhan yang lebih intensif untuk lebih banyak memberikan informasi terbaru mengenai teknik budidaya sayuran hidroponik dengan menggunakan teknologi tepat guna. Dan untuk pengabdian selanjutnya diharapkan dapat menggandeng tidak hanya satu mitra saja sehingga hasilnya dapat dirasakan lebih luas manfaatnya bagi masyarakat

\section{Ucapan Terima Kasih}

Ucapan terima kasih kami sampaikan kepada LPPM UNISSULA yang telah memberikan dana pada program pengabdian ini serta pihak-pihak yang mendukung sehingga kegiatan ini dapat berjalan dengan baik dan lancar.

\section{DAFTAR PUSTAKA}

Aksa, M., Jamaluddin P, J. P., \& Yanto, S. (2018). Rekayasa Media Tanam Pada Sistem Penanaman Hidroponik Untuk Meningkatkan Pertumbuhan Tanaman Sayuran. Jurnal Pendidikan Teknologi Pertanian, 2(2), 163. https://doi.org/10.26858/jptp.v2i2.5172

Badan Pusat Statistik Kabupaten Jepara. (2021). Kabupaten Jepara Dalam Angka 2021.

Izzuddin, A. (2016). Wirausaha Santri Berbasis Budidaya Tanaman Hidroponik. Dimas: Jurnal Pemikiran Agama Untuk Pemberdayaan, 16(2), 351. https://doi.org/10.21580/dms.2016.162.1097

Sagaf, M., Setiyowati, D., Kusumodestoni, R. H., \& Hidayat, S. (2021). Program Pengembangan Produk Unggulan Daerah Jamur Tiram Di Desa Mindahan Kidul Kabupaten Jepara. Abdimas Unwahas, 6(1), 37-45. https://doi.org/10.31942/abd.v6i1.4431 
Swastika, S., Yulfida, A., \& Sumitro, Y. (2017). Budidaya Sayuran Hidroponik. http://riau.litbang.pertanian.go.id/kopitani/images/pdf/juknis/juknishidroponik.pdf 